\title{
Prevalence and specificity of clinically significant red cell alloantibodies in pregnant women - a study from a tertiary care hospital in Southeast Michigan
}

This article was published in the following Dove Press journal: Journal of Blood Medicine

\section{Imran Moinuddin \\ Craig Fletcher \\ Peter Millward}

Department of Pathology and Laboratory Medicine, Beaumont Hospital, Royal Oak, MI 48073, USA
Correspondence: Imran Moinuddin Department of Pathology and Laboratory Medicine, Beaumont Hospital, 9190 Springfield Road, Apt. 27A, Poland 445I4, $\mathrm{OH}$, USA

Tel +I 2486866255

Email imranmoin80@yahoo.com
Background: Maternal red cell IgG antibodies can cross the placenta and cause hemolysis of fetal red cells in case of antigenic differences between maternal and fetal RBCs, leading to hemolytic disease of the fetus and newborn (HDFN). Although the incidence of anti-D associated HDFN has drastically reduced with Rh immune globulin prophylaxis, HDFN due to other maternal red cell alloantibodies still remains a concern. Prevalence and specificities of clinically significant red cell alloantibodies in pregnant females have rarely been reported in the USA.

Methods: A retrospective chart review was conducted to determine the prevalence and specificity of clinically significant red cell alloantibodies in pregnant females who delivered at Beaumont Hospital Royal Oak between May 1, 2017 and December 31, 2017. A total of 4548 pregnant females were screened using electronic medical records. One female above 50 years age and two females with invalid ABO type were excluded from the study per IRB approved protocol. The remaining 4545 pregnant females with a valid $\mathrm{ABO} / \mathrm{RhD}$ type and valid red cell antibody screen were included.

Results: Out of the 4545 included females, 440 had a positive red cell antibody screen. Of these 440 females, 34 had clinically significant alloantibodies, giving an overall prevalence of $0.74 \%$. Anti-E was the most frequently identified significant alloantibody followed by anti-K. The most prevalent significant alloantibodies in $\mathrm{RhD}$ positive and $\mathrm{RhD}$ negative females were anti-E and anti-K, respectively. Significant association ( $p$-value $<0.001$ ) was found between $\mathrm{RhD}$ type and the presence of clinically significant alloantibodies amongst females with positive antibody screen.

Conclusion: Our study aims to reiterate the importance of maternal red cell antibody screening during early pregnancy to help identify and manage high-risk pregnancies. Minimizing the exposure of childbearing age females to incompatible red cell antigens through unnecessary transfusions can help reduce the incidence of red cell alloimmunization and the risk of HDFN.

Keywords: alloantibodies, alloimmunization, hemolytic disease of the fetus and newborn, prevalence, $\mathrm{Rh}$ immune globulin prophylaxis

\section{Introduction}

Hemolytic disease of the fetus and newborn (HDFN) is a clinical condition that occurs as a result of hemolysis of fetal or neonatal red blood cells (RBCs) due to maternal red cell IgG antibodies that can cross the placenta. HDFN is characterized by fetal or neonatal anemia, hyperbilirubinemia and sometimes even fatal hydrops fetalis, and can occur in case of antigenic difference between maternal and fetal RBCs. Clinically significant red cell alloantibodies are those that have the potential 
to cause hemolysis of red cells bearing the corresponding antigen. ${ }^{1}$ Maternal antibodies capable of causing HDFN could either be $\mathrm{ABO}$ antibodies or non-ABO alloantibodies that can develop in the mother due to sensitization following a blood transfusion or previous pregnancy with red cell antigenic differences. ${ }^{2}$

Before the introduction of RhIG, maternal anti-D alloimmunization was the most common cause of HDFN. However, strict implementation of RhIG prophylaxis has drastically reduced the incidence of anti-D associated HDFN over the last half-century. Introduction of postnatal RhIG administration in the late 1960s brought the incidence of $\mathrm{RhD}$ associated HDFN in the USA down from 45.1 per 10,000 births in the early 1970 s to 10.6 per 10,000 births in the mid-1980s. ${ }^{3}$ Incidence of $\mathrm{RhD}$ associated HDFN decreased further to as low as $0.1 \%$ with the implementation of antenatal RhIG immunoprophylaxis. ${ }^{4}$ Consequently, $\mathrm{ABO}$ and other maternal alloantibodies have now emerged as a major cause of HDFN in developed countries. ${ }^{2}$ Studies investigating the prevalence of red cell alloantibodies amongst pregnant women have been done in different countries including Croatia, Netherlands, Spain, Nigeria, Norway, Australia, and China. ${ }^{6,8-13}$ Prevalence of clinically significant red cell alloantibodies has been reported to be anywhere between $0.3 \%$ and $3.4 \%$ in different studies. ${ }^{5-13}$ Current practice in the USA recommends red cell antibody screening for all pregnant females at their first prenatal visit. However, frequencies and specificities of clinically significant red cell alloantibodies in pregnant females have rarely been reported in the USA; particularly in the Midwestern USA. We conducted a retrospective chart review study to determine the frequency and specificity of clinically significant red cell alloantibodies in pregnant females (based on their $\mathrm{ABO}$ and $\mathrm{RhD}$ type) who delivered at Beaumont Hospital Royal Oak between May 1, 2017 and December 31, 2017. In addition, we compared our study findings with some similar studies done in the past in different countries of the world.

\section{Methods}

Approval for this retrospective chart review study was obtained from the Beaumont Research Institutional Review Board. A waiver of patients' consent was approved by Beaumont Research IRB for this retrospective chart review study as it did not influence the patient care or clinical outcome, nor did this chart review study cause any harm to the patients. Patients' data confidentiality was strictly maintained, and the study was conducted in compliance with the Declaration of Helsinki. Using the Beaumont Health System electronic medical records, 4548 pregnant females were screened based on newborn deliveries that took place at Beaumont Hospital Royal Oak between May 1, 2017 and December 31, 2017. One pregnant female who delivered between these dates was above the age of 50 years and was excluded from the study per IRB approved protocol. We performed a retrospective chart review of the remaining 4547 pregnant females aged between 13 and 50 years who delivered at Beaumont Hospital Royal Oak between these dates. In two out of these 4547 females, ABO group could not be determined, and therefore they were also excluded from the study. The remaining 4545 obstetric patients who had a valid/confirmed $\mathrm{ABO} \mathrm{RhD}$ typing and a valid red cell antibody screening were included in the study. Types of data that were collected include: patient's age, date of delivery, $\mathrm{ABO}$ and $\mathrm{RhD}$ type of the pregnant females, red cell antibody screen results, antibody specificity in case of positive red cell antibody screen, history of RhIG administration, gravida status of females with clinically significant alloantibodies, and antibody titers of clinically significant antibodies. Results from duplicate samples from the same patient were excluded from the total. History of RhIG administration during pregnancy was confirmed by review of medical records. Charts of obstetric patients with a positive red cell antibody screen were further reviewed to determine the specificity of red cell alloantibodies. RBC alloantibodies that are known to cause HDFN were considered clinically significant. All anti-D antibodies that developed as a result of documented RhIG administration were considered clinically insignificant in addition to other red cell alloantibodies that are not known to cause HDFN as mentioned in AABB guidelines. ${ }^{14}$

$\mathrm{ABO} / \mathrm{RhD}$ typing and antibody screening were performed using the gel card methodology with automated blood bank analyzers Ortho ProVue, whereas the specificity of antibodies was identified with indirect antiglobulin testing using the manual gel card methodology. Statistical analysis was performed by the biostatistics department at Beaumont Hospital Royal Oak using chi-square for proportion and frequency comparisons to determine the association of $\mathrm{ABO}$ and $\mathrm{RhD}$ types and the presence of clinically significant alloantibodies.

\section{Results}

In this retrospective chart review study, we determined the prevalence and specificity of clinically significant maternal 
red cell alloantibodies known to cause HDFN according to $\mathrm{ABO}$ and $\mathrm{RhD}$ type. Out of 4545 females that were included in our study, $440(9.7 \%)$ females had a positive red cell antibody screen, with 34 of them having one or more clinically significant alloantibodies. The remaining 406 pregnant females with a positive red cell antibody screen had only clinically insignificant red cell alloantibodies, including 372 females with RhIG induced anti-D. The prevalence of clinically significant red cell alloantibodies amongst 440 females with positive antibody screen was $7.7 \%$ or overall $0.74 \%$ amongst all 4545 pregnant females included in our study. Out of 4545 pregnant women included in our study, $44.4 \%$ females belonged to blood group O, 35.4\% belonged to group A, 15\% belonged to group $\mathrm{B}$, and $5.1 \%$ females belonged to group $\mathrm{AB}$. Numerical distribution of total pregnant females included in the study as well as females with positive red cell antibody screen according to ABO type is shown in Table 1 . The numbers of pregnant females with clinically significant alloantibodies by blood group $\mathrm{O}, \mathrm{A}, \mathrm{B}$, and $\mathrm{AB}$ were $10,16,5$ and 3 , respectively, making a total of 34 . The likelihood (prevalence rate) that group $\mathrm{O}$ females with positive red cell antibody screen had a clinically significant alloantibody was $5.5 \%$, as compared to $9.2 \%$ for group A, 8.6\% for group B and $11.1 \%$ for group $\mathrm{AB}$ females. In pregnant females with positive red cell antibody screen, prevalence ratio (for clinically significant red cell alloimmunization) with respect to blood group $\mathrm{O}$ was calculated to be 1.68 for group A, 1.57 for group B and 2.02 for group $\mathrm{AB}$ females. No significant association ( $p$-value $>0.05$ ) was found between ABO groups and the presence of clinically significant alloantibodies in females with positive red cell antibody screen (Table 1).

Out of 4545 pregnant females included in our study, 3998 (88\%) females were $\mathrm{RhD}$ positive and 547 (12\%) females were $\mathrm{RhD}$ negative. Out of the 34 obstetric patients with clinically significant alloantibodies, $28(82.4 \%)$ were $\mathrm{RhD}$ positive and 6 $(17.6 \%)$ were $\mathrm{RhD}$ negative. In regards to $\mathrm{RhD}$ type, prevalence rate and prevalence ratio for having clinically significant red cell alloantibodies in females with positive red cell antibody screen are shown in Table 2 . There was a significant association between $\mathrm{RhD}$ type and the presence of clinically significant alloantibodies (chi-square $p$-value $<0.001$ ) amongst females with positive antibody screen.

Table I Distribution of pregnant females and prevalence rates/ratios of clinically significant red cell alloantibodies according to ABO type

\begin{tabular}{|c|c|c|c|c|}
\hline & \multicolumn{4}{|c|}{$\begin{array}{l}\text { Total number of females included } \\
(n=4545)\end{array}$} \\
\hline & $\mathbf{0}$ & $\mathbf{A}$ & B & $\mathbf{A B}$ \\
\hline No. of pregnant females included & 2020 & 1611 & 680 & 234 \\
\hline Females with positive red cell antibody screen $(n=440)$ & 182 & 173 & 58 & 27 \\
\hline Prevalence rate of positive red cell antibody screen & $9.0 \%$ & $10.7 \%$ & $8.5 \%$ & $11.5 \%$ \\
\hline Females with clinically significant alloantibodies $(n=34)$ & 10 & 16 & 5 & 3 \\
\hline Prevalence rate of clinically significant alloantibodies in females with positive red cell antibody screen & $5.5 \%$ & $9.2 \%$ & $8.6 \%$ & $11.1 \%$ \\
\hline Prevalence ratio of clinically significant alloantibodies in females with positive red cell antibody screen & 1.00 & 1.68 & 1.57 & 2.02 \\
\hline$p$-values (in females with positive red cell antibody screen) & & 0.196 & $0.4 \mathrm{II}$ & 0.285 \\
\hline
\end{tabular}

Table 2 Distribution of pregnant females and prevalence rates/ratios of clinically significant red cell alloantibodies according to RhD type

\begin{tabular}{|l|l|l|}
\hline \multicolumn{2}{|l|}{} & \multicolumn{2}{l|}{$\begin{array}{l}\text { Total number of females included } \\
(\mathbf{n}=\mathbf{4 5 4 5})\end{array}$} \\
\cline { 2 - 3 } & RhD positive & RhD negative \\
\hline No. of pregnant females included & 3998 & 547 \\
Females with positive red cell antibody screen ( $=440)$ & 69 & 371 \\
Prevalence rate of positive red cell antibody screen & $1.7 \%$ & $67.8 \%$ \\
Females with clinically significant alloantibodies ( $\mathrm{n}=34)$ & 28 & 6 \\
Prevalence rate of clinically significant alloantibodies in females with positive red cell antibody screen & $40.6 \%$ & $1.6 \%$ \\
Prevalence ratio of clinically significant alloantibodies in females with positive red cell antibody screen & 1.00 & 0.04 \\
p-values (in females with positive red cell antibody screen) & & $<0.00 \mathrm{I}$ \\
\hline
\end{tabular}


In our study, 28 out of 34 females with clinically significant red cell antibodies were multigravida and 6 females were primigravida (Table 3). Out of 34 females with clinically significant red cell alloantibodies, 6 (17.6\%) females had more than one clinically significant alloantibody; all of them being multigravida, indicating a higher risk of multiple red cell alloimmunization with subsequent pregnancies. Twenty-five out of 34 (73.5\%) females were identified to have the clinically significant alloantibody during their second or subsequent pregnancy; whereas $9(26.5 \%)$ females had clinically significant red cell alloantibody during their first pregnancy (2 out of these 9 females were identified to have the alloantibody even prior to their first pregnancy).

Overall, in our study population, the most frequently identified clinically significant red cell alloantibody was anti-E $(\mathrm{n}=13 ; 38.2 \%)$ followed by anti-K $(\mathrm{n}=7 ; 20.6 \%)$ and anti-M $(n=6 ; 17.6 \%)$. The total number of clinically significant alloantibodies identified in 34 females was 42 with
14 different antibody specificities. Distribution of identified clinically significant alloantibodies according to $\mathrm{ABO}$ and $\mathrm{RhD}$ type is shown in Table 4. Out of all 34 females with clinically significant alloantibodies, only one female with anti-K had a critical titer of 1:16 at some point during her pregnancy, but no adverse clinical outcome was reported in the mother or neonate. Three out of 34 females with clinically significant alloantibodies required blood transfusion during pregnancy ( 1 due to sickle cell disease, 1 due to beta-thalassemia minor and 1 due to alpha thalassemia trait).

\section{Discussion}

HDFN is an important clinical entity that needs to be dealt with aggressively to avoid undesirable clinical outcomes. HDFN due to anti-D alloimmunization was a major cause of fetal and neonatal mortality until the early 1970s. ${ }^{3}$ Introduction and implementation of RhIG administration over the last few decades have significantly reduced the

Table 3 Gravida status of females with clinically significant alloantibodies in relation to $A B O$ and RhD type

\begin{tabular}{|c|c|c|c|c|c|c|c|}
\hline \multirow[t]{2}{*}{ Gravida status of females with significant alloantibodies $(n=34)$} & \multicolumn{4}{|c|}{ ABO type } & \multirow[t]{2}{*}{ Total } & \multicolumn{2}{|l|}{ RhD type } \\
\hline & $\mathbf{0}$ & $\mathbf{A}$ & B & AB & & D positive & D negative \\
\hline Primigravida & I & 3 & I & I & 6 & 5 & I \\
\hline Multigravida & 9 & 13 & 4 & 2 & 28 & 23 & 5 \\
\hline TOTAL & 10 & 16 & 5 & 3 & 34 & 28 & 6 \\
\hline
\end{tabular}

Table 4 Overall distribution of specific clinically significant red cell alloantibodies in pregnant females according to $A B O$ and RhD type

\begin{tabular}{|c|c|c|c|c|c|c|}
\hline \multirow[t]{3}{*}{ Antibody specificity } & \multicolumn{6}{|c|}{$\begin{array}{l}\text { Number of pregnant females with specific clinically significant alloantibodies according to } A B O \text { and RhD } \\
\text { type }\end{array}$} \\
\hline & \multicolumn{4}{|c|}{ ABO type } & \multicolumn{2}{|l|}{ RhD type } \\
\hline & 0 & A & B & AB & D positive & D negative \\
\hline$C+D$ & & 1 & & & & I \\
\hline$C+D+G$ & 1 & & & & & I \\
\hline c & & 2 & & & 2 & \\
\hline E & 5 & 4 & 1 & I & 11 & \\
\hline $\mathrm{E}+\mathrm{Fy}^{\mathrm{a}}$ & & I & & & 1 & \\
\hline$E+C^{w}$ & & I & & & I & \\
\hline $\mathrm{C}+\mathrm{K}+\mathrm{e}$ & & । & & & I & \\
\hline$c+\mathrm{Jk}^{\mathrm{a}}$ & I & & & & I & \\
\hline K & 1 & 3 & 1 & 1 & 2 & 4 \\
\hline$J k^{a}$ & & I & & & I & \\
\hline $\mathrm{Jk}^{\mathrm{b}}$ & & I & & & I & \\
\hline M & 2 & 1 & 2 & 1 & 6 & \\
\hline $\mathrm{s}$ & & & 1 & & I & \\
\hline SUBTOTAL & 10 & 16 & 5 & 3 & 28 & 6 \\
\hline TOTAL & 34 & & & & 34 & \\
\hline
\end{tabular}


incidence of anti-D associated HDFN to as low as $0.1 \%$, particularly in developed countries, ${ }^{4}$ and red cell alloantibodies other than anti-D have now emerged as a major cause of HDFN. ${ }^{2}$ Prevalence of clinically significant red cell alloimmunization in pregnant females reported in studies from different countries ranges between $0.3 \%$ and $3.4 \% .^{5-13}$ In our study, the prevalence of clinically significant red cell alloimmunization was 740 per 100,000 pregnant females $(0.74 \%)$.

In our study, a total of 440 females (9.7\%) out of 4545 screened females had positive red cell antibody screen. Results from Smith et $\mathrm{al}^{7}$ showed a presence of $\mathrm{RBC}$ antibodies in $3 \%$ of all the screened obstetric patients and a presence of clinically significant alloantibodies in $40.5 \%$ of these patients or in $1.2 \%$ of all obstetric patients included in the study. The difference in the prevalence of positive antibody screen between our study and the study by Smith et al is due to the fact that females with RhIG induced anti-D were not included in the study conducted by Smith et al. In a study conducted by Jeremiah et $\mathrm{al}^{10}$ in Nigeria, positive red cell alloantibody screen was reported in $23(4.6 \%)$ out of 500 pregnant females. Prevalence of positive antibody screen at first-trimester screening was reported to be 1232 in 100,000 (1.2\%) pregnant females by Koelewijn et $\mathrm{al}^{15}$ whereas, in a study conducted by Shahverdi et al $^{16}$ that included 7340 pregnant females, $4.5 \%$ females had positive red cell antibody screen.

Overall clinically significant red cell alloimmunization prevalence in our study was $0.74 \%$ or 740 per 100,000 pregnant females. This is somewhat higher than that reported by Dajak et $\mathrm{al}^{6}(0.42 \%)$ in Croatia and Solves et $\mathrm{al}^{9}(0.63 \%)$ in Spain, but lower than the prevalence reported by Smith et $\mathrm{al}^{7}(1.2 \%)$ and Jeremiah et $\mathrm{al}^{10}$ (3.4\%). Koelewijn et $\mathrm{al}^{15}$ reported the prevalence of pregnancies with clinically significant alloantibodies other than anti-D to be $0.3 \%$ (328 in 100,000). In a 12-month study conducted in the Malay population, 30 (0.58\%) out of 5163 pregnant females were found to have clinically significant red cell alloantibodies. ${ }^{5}$ In a longitudinal cohort study conducted by De Vrijer et $\mathrm{al}^{8}$ in the Netherlands, 2392 pregnant females were screened and the overall incidence of red cell alloimmunization was reported to be $2.7 \%$, with the incidence of non-RhD alloantibodies to be $1.6 \%$. Lee et $\mathrm{al}^{13}$ conducted a retrospective study in Hong Kong from 1997 to 2001 that included 26,883 pregnant females and reported the prevalence of significant red cell alloantibodies to be $0.31 \%$ in the overall study population and $0.27 \%$ amongst females with Chinese ethnicity.

The most frequently identified significant alloantibody in our study was anti-E (38.2\%) followed by anti-K (20.6\%) and anti-M (17.6\%). In a study conducted by Hassan et $\mathrm{al}^{5}$ in the Malay population, anti-E (33.3\%) followed by anti-D $(10 \%)$ were the two most commonly identified significant alloantibodies. In the study conducted by Smith et al, ${ }^{7}$ the three most frequently identified clinically significant antibodies were anti-E (31\%) followed by anti-M (24.3\%) and anti-D (18.7\%). Jeremiah et $\mathrm{al}^{10}$ in their study from Nigeria reported the prevalence of clinically significant red cell alloantibodies to be $3.4 \%$ in pregnant females, with anti-C being the most frequent followed by anti-K. In a cohort study $^{11}$ involving 55,462 consecutive antibody screening tests from a tertiary Western Norwegian Hospital, the two most frequent RBC alloantibodies in pregnant women were anti-M (20.8\%) and anti-D (18.9\%). The most prevalent clinically significant red cell alloantibody identified by $\mathrm{Pal}$ and Williams ${ }^{12}$ was also anti-E (27.6\%), followed by antiD (10.4\%), anti-K (9.5\%) and anti-C (8.7\%). In the study conducted by Koelewijn et al, ${ }^{15}$ the most common non-RhD alloantibody was also anti-E followed by anti-K and anti-C.

The second most frequently identified significant red cell alloantibody in our study population was anti-K. Out of 34 pregnant females with clinically significant red cell alloantibodies, $7(20.6 \%)$ were found to have anti-K with an overall prevalence of $0.15 \%$, which is higher than in some other studies. ${ }^{6,15}$ Fetal anemia in case of anti-K alloimmunization is mainly caused by the suppression of marrow erythropoiesis directly induced by anti-K antibodies, as opposed to other alloantibodies which act mainly by causing direct hemolysis. ${ }^{17,18}$ Anti-K was the second most frequently identified significant alloantibody after anti-D in the study conducted by Dajak et $\mathrm{al}^{6}$ and accounted for almost $13 \%$ of all clinically significant red cell alloantibodies with an overall prevalence of $0.05 \%$. Koelewijn et $\mathrm{al}^{15}$ reported the prevalence of anti-K antibodies to be 79 per 100,000 , or $0.08 \%$.

In our study, anti-M was identified in 6 out of 34 patients having clinically significant alloantibodies and was identified as the most frequent alloantibody in group $\mathrm{B}$ obstetric patients. Anti-M is mostly an IgM naturally occurring antibody, but the IgG class of anti-M has also been reported to cause HDFN. ${ }^{19,20}$ Frequency of anti-M has been reported to be $10 \%$ in pregnant women with positive antibody screen. ${ }^{21}$ Wikman et $\mathrm{al}^{21}$ reported anti$\mathrm{M}$ in a female during her three consecutive pregnancies 
causing severe HDFN, with one fetus dying at 20 weeks of gestation due to hydrops fetalis.

In our study population, anti-E $(n=13 ; 46.4 \%)$ followed by anti-M ( $\mathrm{n}=6 ; 21.4 \%)$ were the most frequently identified clinically significant alloantibodies in $\mathrm{RhD}$ positive females, whereas anti-K $(n=4 ; 66.6 \%)$, followed by anti-D $(n=2 ; 33.3 \%)$ and anti-C $(n=2 ; 33.3 \%)$ were the most frequently identified antibodies in $\mathrm{RhD}$ negative pregnant females. Results from a study by Smith et $\mathrm{al}^{7}$ showed antiE followed by anti-M and anti-K to be the most frequently identified significant alloantibodies amongst $\mathrm{RhD}$ positive females, whereas anti-D followed by anti-C and anti-E were the most frequently identified alloantibodies in $\mathrm{RhD}$ negative females.

In our study, out of 34 females with clinically significant red cell alloantibodies, $6(17.6 \%)$ females had more than one clinically significant alloantibody. This is comparable to the findings of Solves et $\mathrm{al}^{9}$ who identified multiple clinically significant alloantibodies in $17.0 \%$ of pregnant females with clinically significant red cell alloantibodies.

Lastly, in regards to $\mathrm{RhD}$ status, our study results showed significant association between RhD type and the presence of clinically significant red cell alloantibodies amongst females with positive antibody screen, implicating that amongst RhD positive females with a positive red cell antibody screen, the likelihood (prevalence rate) of having a clinically significant alloantibody was $40.6 \%$, whereas it was $1.6 \%$ for $\mathrm{RhD}$ negative females with a positive red cell antibody screen. In contrast, the overall prevalence rate of positive red cell antibody screen was much higher in $\mathrm{RhD}$ negative females as compared to $\mathrm{RhD}$ positive females (67.8\% and $1.7 \%$, respectively), which was mostly due to prophylactically administered RhIG induced clinically insignificant anti-D causing positive antibody screen in RhD negative females.

\section{Conclusion}

The overall prevalence of clinically significant red cell alloantibodies in our study population was $0.74 \%$, which is slightly higher than the prevalence reported in European countries, and somewhat lower than in South Asian and African countries. This difference is likely due to genetic and racial variations in different parts of the world, different study population sizes, and possibly some difference in blood bank testing methodologies. Anti-E and anti-K were the two most frequently identified clinically significant red cell alloantibodies in our study population. The findings of our study aim to re-emphasize the importance of screening and detection of red cell alloantibodies early in pregnancy to help identify and appropriately manage high-risk pregnancies, in addition to increasing the understanding amongst pregnant females about these antibodies and the associated risk of HDFN. We recommend minimizing the exposure of females of childbearing age to incompatible red blood cell antigens through unnecessary transfusions to help further reduce the overall incidence of red cell alloimmunization as well as the risk of HDFN.

\section{Disclosure}

The authors report no conflicts of interest in this work.

\section{References}

1. Milkins C, Berryman J, Cantwell C, et al. Guidelines for pre-transfusion compatibility procedures in blood transfusion laboratories. British Committee for Standards in Hematology. Transfus Med. 2013;23(1):3-35. doi:10.1111/j.1365-3148.2012.01199.x

2. Basu S, Kaur R, Kaur G. Hemolytic disease of the fetus and newborn: current trends and perspectives. Asian J Transfus Sci. 2011;5 (1):3-7. doi:10.4103/0973-6247.75963

3. Chavez GF, Mulinare J, Edmonds LD. Epidemiology of Rh hemolytic disease of the newborn in the United States. J Am Med Assoc. 1991;265(24):3270-3274. doi:10.1001/jama.1991.03460240066029

4. Liumbruno GM, D'alessandro A, Rea F, et al. The role of antenatal immunoprophylaxis in the prevention of maternal foetal anti $\mathrm{Rh}$ (D) alloimmunisation. Blood Transfus. 2010;8(1):8-16. doi:10.2450/ 2009.0108-09

5. Hassan MN, Mohd Noor NH, Johan Noor SR, et al. Hemolytic disease of fetus and newborn due to maternal red blood cell alloantibodies in the Malay population. Asian J Transfus Sci. 2014;8(2):113117. doi:10.4103/0973-6247.137449

6. Dajak S, Stefanović V, Capkun V. Severe hemolytic disease of fetus and newborn caused by red blood cell antibodies undetected at first-trimester screening. Transfusion. 2011;51(7):1380-1388. doi:10.1111/j.15372995.2010.03006.x

7. Smith HM, Shirey RS, Thoman SK, Jackson JB. Prevalence of clinically significant red blood cell alloantibodies in pregnant women at a large tertiary-care facility. Immunohematology. 2013;29 (4):127-130.

8. de Vrijer B, Harthoorn-Lasthuizen EJ, Oosterbaan HP. The incidence of irregular antibodies in pregnancy: a prospective study in the region of the 's-Hertogenbosch. Ned Tijdschr Geneeskd. 1999;143(50):2523-2527.

9. Solves P, Gomez-Segui I, Guinot M, et al. Prevalence of red cell antibodies in pregnant women and hemolytic disease of newborn in a tertiary care hospital. ARC J Gynaecol Obstet. 2017;2(2):18-22.

10. Jeremiah ZA, Mordi A, Buseri FI, Adias TC. Frequencies of maternal red blood cell alloantibodies in Port Harcourt, Nigeria. Asian $J$ Transfus Sci. 2011;5(1):39-41. doi:10.4103/0973-6247.75987

11. Erikstein BS, Hagen KG, Hervig T. RBC alloantibody prevalence and specificity in a Western Norwegian tertiary hospital. Transfus Med. 2018. doi:10.1111/tme.12511

12. Pal M, Williams B. Prevalence of maternal red cell alloimmunisation: a population study from Queensland, Australia. Pathology. 2015;47 (2):151-155. doi:10.1097/PAT.0000000000000225

13. Lee CK, Ma ES, Tang M, Lam CCK, Lin CK, Chan LC. Prevalence and specificity of clinically significant red cell alloantibodies in Chinese women during pregnancy-a review of cases from 1997 to 2001. Transfus Med. 2003;13(4):227-231. 
14. Judd WJ; The 2003-2004 Scientific Section Coordinating Committee. Guidelines for Prenatal and Perinatal Immunohematology. 1st ed Bethesda, MD: AABB; 2005.

15. Koelewijn JM, Vrijkotte TGM, van der Schoot CE, Bonsel GJ, de Haas M. Effect of screening for red cell antibodies, other than anti-D, to detect hemolytic disease of the fetus and newborn: a population study in the Netherlands. Transfusion. 2008;48(5):941-952. doi:10.1111/j.1537-2995.2007.01625.x

16. Shahverdi E, Moghaddam M, Gorzin F. Maternal red blood cell alloantibodies identified in blood samples obtained from Iranian pregnant women: the first population study in Iran. Transfusion. 2017;57(1):97-101. doi:10.1111/trf.13867

17. Vaughan JI, Warwick R, Letsky E, Nicolini U, Rodeck CH, Fisk NM. Erythropoietic suppression in fetal anemia because of Kell alloimmunization. Am J Obstet Gynecol. 1994;171(1):247-252. doi:10.1016/0002-9378 (94)90477-4
18. Weiner CP, Widness JA. Decreased fetal erythropoiesis and hemolysis in Kell hemolytic anemia. Am J Obstet Gynecol. 1996;174 (2):547-551. doi:10.1016/s0002-9378(96)70425-8

19. Heathcote DJ, Carroll TE, Flower RL. Sixty years of antibodies to MNS system hybrid glycophorins: what have we learned? Transfus Med Rev. 2011;25(2):111-124. doi:10.1016/j.tmrv. 2010.11.003

20. Yasuda H, Ohto H, Nollet KE, et al. Hemolytic disease of the fetus and newborn with late-onset Anemia due to Anti-M: a case report and review of the Japanese literature. Transfus Med Rev. 2014;28 (1):1-6. doi:10.1016/j.tmrv.2013.10.002

21. Wikman A, Edner A, Gryfelt G, Jonsson B, Henter J-I. Fetal hemolytic anemia and intrauterine death caused by anti-M immunization. Transfusion. 2007;47(5):911-917. doi:10.1111/j.15372995.2007.01209.x

\section{Publish your work in this journal}

The Journal of Blood Medicine is an international, peer-reviewed, open access, online journal publishing laboratory, experimental and clinical aspects of all aspect pertaining to blood based medicine including but not limited to: Transfusion Medicine; Blood collection, Donor issues, Transmittable diseases, and Blood banking logistics; Immunohematology; Artificial and alternative blood based therapeutics; Hematology; Biotechnology/nanotechnology of blood related medicine; Legal aspects of blood medicine; Historical perspectives. The manuscript management system is completely online and includes a very quick and fair peer-review system. Visit http://www.dovepress.com/testimonials.php to read real quotes from published authors. 